\title{
On $\alpha$-nonexpansive mappings in Banach spaces
}

\section{DAVID ARIZA-RuiZ, CARLOS HERnÁNDEZ LinARES, ENRIQUE LLORENS-Fuster and ELENA MORENO-GÁLVEZ}

\section{ABSTRACT.}

In 2011 Aoyama and Kohsaka introduced the $\alpha$-nonexpansive mappings. Here we present a further study about them and their relationships with other classes of generalized nonexpansive mappings.

Acknowledgements. The authors would like to thank the referees for their valuable comments. The first author has been supported by grants MTM2012-34847-C02-01 and P08-FQM-03453. The second author has been supported by a grant from CONACYT (México). The third and the fourth authors have been partially supported by grant MTM2012-34847-C02-02.

\section{REFERENCES}

[1] Aoyama, K., Iemoto, S., Kohsaka, F. and Takahashi, W., Fixed point and ergodic theorems for $\lambda$-hybrid mappings in Hilbert spaces, J. Nonlinear Convex Anal., 11 (2010), 335-343

[2] Aoyama, K. and Kohsaka, F., Fixed point theorem for $\alpha$-nonexpansive mappings in Banach spaces, Nonlinear Analysis Series A: Theory, Methods \& Applications, 74 (2011), No. 13, 4387-4391

[3] Bae, J. S., Fixed point theorems of generalized nonexpansive mappings, J. Korean Math. Soc., 21 (1984), No. 2, 233-248

[4] Bogin, J., A generalization of a fixed point theorem of Goebel, Kirk and Shimi, Canad. Math. Bull., 19 (1976), 7-12

[5] Bruck, R. E., Nonexpansive projections on subsets of Banach spaces, Pacific J. Math., 47 (1973), 341-355

[6] Dhompongsa, S. and Nanan, N., Fixed point theorems by ways of ultra-asymptotic centers, Abstr. Appl. Anal., 2011, Art. ID 826851, 21 pp.

[7] Goebel, K., Kirk, W. A. and Shimi, T. N., A fixed point theorem in uniformly convex spaces, Boll. Un. Mat. Ital., 7 (1973), 67-75

[8] Hong, Y. M. and Huang, Y. Y., On ג-firmly nonexpansive mappings in nonconvex sets, Bull. Inst. Math. Acad. Sinica, 21 (1993), 35-42

[9] Japón-Pineda, M. A. and Goebel, K., On a type of generalized nonexpansiveness, Proceedings of the 8th International Conference of Fixed Point Theory and its Applications, pp. 71-82, Yokohama Publishers, 2008

[10] Kohsaka, F. and Takahashi, W., Fixed point theorems for a class of nonlinear mappings related to maximal monotone operators in Banach spaces, Arch. Math. (Basel), 91 (2008), 166-177

[11] Llorens-Fuster, E. and Moreno-Galvez, E., The fixed point theory for some generalized nonexpansive mappings, Abstr. Appl. Anal. 2011, Art. ID 435686, 15 pp.

[12] Takahashi, W., Fixed point theorems for new nonlinear mappings in a Hilbert space, J. Nonlinear Convex Anal., 11 (2010), No. 1, 79-88

[13] Takahashi, W. and Yao, J. C., Fixed point theorems and ergodic theorems for nonlinear mappings in Hilbert spaces, Taiwan J. Math., 15 (2011), 457-472

Received: 07.01.2014; In revised form: 28.04.2014; Accepted: 05.05.2014

2010 Mathematics Subject Classification. 47H06, 47H09, 47H10.

Key words and phrases. Firmly nonexpansive mappings, fixed point theorem nonexpansive mappings, nonspreading mappings, hybrid mappings.

Corresponding author: E. Llorens-Fuster; enrique.1lorens@uv.es 
Department of Mathematical ANALYSis

UNIVERSITY OF SEVILLA (SPAIN)

AVDa. TARFIA S/N, SEVIlla, Spain

E-mail address: dariza@us.es

UNIVERSIDAD VeracruZANA (MÉXICO)

CirCuito GonZalo Aguirre Beltrán S/N, Zona Universitaria

Xalapa, VeracruZ, MeXico. C.P. 91090

E-mail address: carlhernandez@uv . mx

Department of Mathematical ANalysis

UNIVERSITY OF VALENCIA (SPAIN)

DR. MOLINER S/N. 46100, BUJASSOT, VALENCIA, SPAIN

E-mail address: enrique.llorenseuv.es

Departamento de DidÁcticas Específicas: Matemáticas

UNIVERSIDAD CATÓLICA DE VALENCIA

46100 Godella, VALENCIA, SPAiN

E-mail address: elena.moreno@ucv.es 